\title{
The Role of University Administration in Enhancing Intellectual Security Among Yarmouk University Students
}

\author{
Najwa Abdel Hamid Darawsha \\ Correspondence: Najwa Abdel Hamid Darawsha, Assistant professor, Collage of education, Jadara University, Jordan.
}

Received: August 27, 2020

doi:10.11114/jets.v9i5.5242

\author{
Accepted: May 23, 2021 \\ Online Published: May 24, 2021 \\ URL: https://doi.org/10.11114/jets.v9i5.5242
}

\begin{abstract}
This study aimed at identifying the role of university administration in enhancing intellectual security among Yarmouk University students from the students' viewpoint. The researcher adopted the descriptive survey method, and the questionnaire was used as a study. The study sample comprised of (385) students. The findings showed that university administration plays a high role in enhancing intellectual security, with a mean of (3.53). As shown the mean of "the role of the university in revitalizing the role of students in enhancing their intellectual security" is (3.75) and with a high degree, followed by "The role of the university in promoting the role of activities in enhancing students' intellectual security" with a mean of (3.43), and also with a high degree. Where the last domain records a high degree and a mean of (4.2).

The results also showed that there are statistically significant differences attributable to the effect of the gender variable, and it is in favor of females, and there are no differences attributable to the impact of the two variables "specialization and place of residence". In light of the findings, the study recommended strengthening communication between the university administration and the society and students to control the problem facing the students in terms of intellectual security, providing educational guidance activities, and disseminating them through the available media and enhancing students' intellectual security by providing university programs and activities, Connecting students to the prevailing culture in society and introducing them to the heritage of their nation, while spreading the spirit of innovation, creativity and brilliance, in response to developments and changes in civilization while not contradicting the foundations and constants of religious beliefs. And Training and accustoming students to discipline, good behavior, and the ability to understand the surrounding circumstances and deal with balance within its framework, wisely away from extremism and negative ideas.
\end{abstract}

Keywords: role, university administration, intellectual security

\section{Introduction}

Undoubtedly, a successful university administration is the one that achieves its goals according to what its society seeks to attain, and that the scientific advancement of any society depends on the quality of the educational outputs that are shaped by the great efforts of successful educational administrative leaders. Therefore, the educational leadership whether in high education or the other sectors is considered an effective tool in bringing about effective development in the performance of administrators, faculty members, and students.

The university is a social institution that has a notable role in influencing the social, economic, and cultural milieu and it is at the same time influenced by its society. On the other hand, the socio-economic conditions and the cultural milieu of a society play a great role in motivating students to continue their university studies and in determining its quality (Omari, 2005).A result of the tremendous scientific and technological knowledge and its huge applications, the levels of university education have risen rapidly and impressively worldwide, as they are the crucial and effective element in embracing young people, preparing them and qualifying them for the labor market (Barro \& Lee, 2013). The university is considered the main center for developing various activities that aim to prepare students with the required competencies. The most prominent characteristic of universities is that they are a cultural, intellectual, and scientific center in its society (Hatamleh \& Darawsha, 2019). Ajez and Nashwan (2005) agree with (Young, 2014) in considering university education as a place where science and knowledge are produced, and that universities play a great role in developing the competencies of students, their attitudes as well as modifying their behaviors, and preparing them successfully to the labor market. 
Intellectual security has become a national and global demand and a strategic vision that makes nations exert their utmost efforts and energy to obtain it. Intellectual security as seen by (Zboun and Enizi, 2017) is the basis and source for other aspects related to security since the individual's actions, attitudes, achievements, and interests are signifying his thoughts, trends, and beliefs. The world nowadays is witnessing rapid developments and changes in various fields, especially in the areas of science, knowledge, and technology which requires giving more attention to the knowledge that university students obtain from various sources as they may be vulnerable to extremist intellectual ideas.

Tayyar (2011) pointed out that this rapid development and changes that have occurred internationally affected society, its institutions, its values, customs, and traditions. These changes have resulted in a rapid increase in the number of crimes, intellectual and behavioral deviations that no longer threaten the life of a person or a society in particular, but rather became a threat to international peace and security in general, and the national security in particular. This fact has prompted many interested researchers in the field of crime prevention, and the attainment of security for societies to demand the active participation of community members and institutions in bearing security responsibility and extend bridges of cooperation with security institutions. Therefore (Dhafiri, 2017: 1) believes that security is the basic pillar upon which all human societies depend, and a major pillar upon which the creativity and giving of humanity is based, and through it, the individual and society feel security and safety, and through it, the interests of people and their requirements are fulfilled.

Where Dino (2017) stated that intellectual security is a legitimate requirement for all individuals and societies, as it is the safety valve against what society may suffer from such as terrorism, and violation of the most basic human rights and society must avoid all attempts to slip into the maze of deviant thought, hence, several social groups have sought to achieve intellectual security to its society to protect them from any possible deviant ideas.

The concept of intellectual security is considered one of the concepts that are noticeably addressed as a result of society's suffering from changes and disturbances in thought, exaggeration, religious extremism, and cultural deterioration, especially among university. It is known that and the imbalance of intellectual security leads to the imbalance of security in the criminal, economic, and other aspects (Al-Harthy, 2008). The issue of intellectual security has been of great importance for university administration which seeks to provide awareness and guidance to students about the dangers of intellectual deviation and to protect everyone who tends to deviate or fall into behavioral problems that may threaten the security of the student, his family, and society. This calls for cooperation and coordination between the university administration, academic leaders, faculty members, parents, and university media on one hand, and working on involving university activities, programs, and seminars in protecting and solving student problems that they may expose to during their university studying. Qarni (2005) divides the role of educational institutions into several stages, starting with awareness and prevention, and ending with evaluation and treatment.

Thus, the central role of university administration in this period is to focus on enhancing students' awareness about intellectual security and fortifying them in the face of extremism and violence, and this is done through organizing periodic student visits to the specialists and scholars to communicate with them for attaining intellectual support. The universities can also hold sessions that emphasize the importance of intellectual security and host some security leaders to discuss the relationship of intellectual security in achieving psychological stability among students, and its negative effects and repercussions on students, society and the state.

This fact is supported by results of the study conducted by Hawari and Adon (2011) as they concluded that the university administration plays a major role in strengthening the academic members' role in promoting the principle of moderation and intellectual security. Shaldan (2013) recommended the need to activate the role of colleges of education in Palestinian universities to enhance intellectual security, and to enable faculty members to play their role in this field. While Al-Azzam (2017) stated the need to strengthen the role of student clubs in enhancing intellectual security according to the perception of Islamic education, Abu Hamam (2017) indicated that the degree of academic leaders strengthening intellectual security and its relationship to the degree of availability of job security in Jordanian universities is still moderate.

Accordingly, the university administration must employ university activities to spread the correct ideas that fight the ideas of stray groups through various electronic means with psychological stability and tightening control over the Internet; which enhances intellectual security, and work to strengthen the role of universities by establishing an intellectual unit within university clubs to spread Sound Islamic values and principles, with the opening of channels of dialogue, and strive to exploit the university facilities such as gymnasiums and various activity halls to direct the students' energies toward beneficial acts, thus reducing the possibility of intellectual deviation.

If the university administration in general and Jordanian universities, in particular, want to perform its educational and advisory role to protect students from the causes of deviation and achieve intellectual security, which may lead to intellectual extremism among students and reflect negatively on the students' stability and psychological security in one 
hand, and the institutional security within the university, their society as a whole and their state. The university administration has been seeking to achieve this stability through the following areas:

- The first field: In addition to the effort made by the university administration to obtain intellectual security and stability among students, and to make them aware of the manifestations of deviation and intellectual extremism through educational programs, guidance seminars, and courses that study the importance of intellectual security and the rejection of extremism, and the university administration's participation in conferences centered on intellectual security and the rejection of extremism, the university administration must attain the goals expected of graduates who are distinguished by sound thinking. The university must also focus on keeping pace with developments to keep pace with development and modernity and developing the ability and skill to urge students to make the best use of modern technologies to know community issues (intellectual security) and to provide students with an opportunity to discuss issues raised in society, and to ensure that students are familiar with the concepts and contents of intellectual security in a manner. It is correct and following up on the behavior of students to identify and monitor deviant ideas.

- The field of university activities: that the university administration's activity is not limited to the theoretical educational aspect. The applied practical side must be strengthened in employing the energy of young people, exploiting their creative ideas, educating them, and guiding them to the institutions that help them to invest their innovations and achievements, in terms of cooperation with the security services in the local community. The university can also publish news of educational activities and programs on intellectual security, direct students to participate in the Quran memorization courses that exist in places of worship, and enhance the relationship with media officials in the neighborhood to enhance students' intellectual security.

If the university administration's role is still focusing on the theoretical field, this will limit the young people aspiration and make them able to be exposed to external sources that invest their intellectual energies for their interests, and the student will be a victim of the to their deviant ideas, as the university must strive to invest students' creative ideas in the investment of knowledge in the light of knowledge economy and technology, and through the introduction of technological means and participation in scientific knowledge networks, for students and researchers to obtain research, books, magazines, periodicals, and scientific research reports, available to students at any time. In addition to helping them in developing their creative ideas and develops awareness among students about the manifestations of extremism and deviation.

- The third field: the role of university administration in strengthening the role of society in enhancing intellectual security among students: through the university administration preparing a systematic plan aiming to develop the relationship with local community institutions to provide awareness programs for students to enhance their intellectual security, invite the attendance of security officials, and provide advice and direct awareness To enhance their intellectual security, and invite the security services to direct students to participate and benefit from programs and activities of places of worship that enhance their intellectual security.

\section{Literature Review}

\section{Definition of intellectual security:}

Buqami (2009: 8) defined intellectual security as: "the pillar of human thought towards extremism and deviation by adhering to the method of moderation in understanding religious issues because the misleading concepts lead to destabilization of security in all its fields." Khamisi (2002) sees that "Intellectual security means preserving the original cultural components from suspicious cultural ideas, which means protecting and maintaining cultural identity from penetration. Hoshan $(2015,9)$ believes that it is "an intellectual approach that adheres to moderation and aims to inculcate moral, educational and ethical values from extremist tendencies".The researcher concludes that it is "protection from threats, dangers, sources, and causes that may distort or strengthen individuals' intellectual convictions or belief constants."

\section{The importance of intellectual security}

The sound idea is a basic pillar in the advancement of nations and peoples, and it is the source of human happiness or misery. If a person draws his thoughts from a trusted source or a sound mind, this will protect him from all the influences and the deviant or misleading beliefs. The importance of intellectual security lies in the fact that it is the basis for building an integrated system of all aspects of security, culture, and ethics. These aspects are combined, and cannot be separated from each other, and any imbalance of thought will be the result of an imbalance in other aspects, which results in a threat to the elements of national security in general (Hakim, 2009).

Al-Husseini (2018) stated that the importance of achieving intellectual security among students lies in securing the integrity of thought, behavior, values, beliefs, and preserving the principles of students from piracy in perception and 
the deviation in thinking. As for the importance of intellectual security. It comes from being protection to the student's mind from delinquency, wrongful acts, and distorted thoughts

\section{Intellectual security goals:}

Intellectual security in every society aims to achieve several goals as stated by Haider (2002), Barashi (2008), Hudlaa (2012), and Al-Shihri (2019), which are:

- Identity preserving, every society has its constants that represent the base upon which they are built, and they are the bond that unites their members, determines their behavior, adapts their reactions to events, gives the society its independence and distinction, and ensures its survival among other nations.

- Protecting minds from intellectual invasion, cultural delinquency, and religious extremism; it is of the security necessities to protect the gains and to stand firmly against everything that leads to a breach of national security

- Intellectual security is one of the foundations of the nation's values, beliefs, and customs. Therefore, it is the first thing enemies tend to attack to achieve their aggressive goals and promote their destructive ideas, especially among the youth, and confuse their thoughts and invite to extremism.

\section{The foundations of intellectual security:}

The blessing of security and stability is one of the greatest blessings that a person can win because he enables him to live in a safe environment where everything he owns is safe as his religion, his money and his family, and that can only be achieved through his believing in God Almighty and avoiding his disobedience. Security is the basis for the prosperity of civilization, the progress of nations, and the advancement of societies, hence, if security is lost, life is disrupted, and progress stops. Islam considers security as a very important goal that protects the soul, security for money, security for honor, and for offspring, these are the five necessities that the Shari'a came to preserve and came to protect all laws and religions (Al-Shehri, 2015).

Al-Turki (2015) addressed the most important elements of intellectual security as follows:

- Imposing the law of God among people because it is the only guarantor of justice and equality among people.

- Reforming the faith with sincerity of worship to God Almighty so that we can enjoy security and safety.

- Promotion of Virtue and Prevention of Vice.

- Thanking the blessings in the heart and the souls, by those blessings in obedience to God.

- The political stability of the state is one of the most important elements in establishing security

- The economic stability of the country, through which everyone can enjoy a good life. Economic stability plays a major role in providing people with their needs and meeting their demands

- The presence of a strong security system which protects the freedom of people

- Adherence to law, implementing regulations and laws and holding those who violate them accountable

- Media commitment to the Islamic middle course.

\section{Summary of the role of university administration in developing youth intellectual security:}

The role of university administration is represented through their interaction with students, activities, and the local community, and protecting students from extremism and terrorism.

As a matter of fact, Security is a demand for all people as it provides a better secure life, hence, intellectual security has become a national obsession, a global demand, and a strategic vision that makes the nations exert their utmost efforts and energies to gain it. Intellectual security is the basis and source for all other aspects of security because the actions of the individual, his attitudes, accomplishments, are a reflection of his ideas and beliefs (Al-Anzi and the customer, 2015).

Intellectual security means reassuring people about the components of their authenticity, their specific culture, and their intellectual system. It is related to the human right to freely think and express his security and protecting all his obtained rights to choose and act in a manner that does not contradict the rights and gains of others. (Tomlinson, 2006).

The educational institutions have an active role in establishing the foundations of security at various levels of education, through providing awareness, prevention, and treatment, especially in the university stage, in which students have become a leader in activity and vitality on the one hand, and more receptive to the flow of ideas and attracting parties regardless to their positive or negative trends (Nasser, 2016). This requires these institutions to carry out their religious and patriotic duty towards directing youth to love for their society, their homeland and their nation, their leaders, and 
their scholars because this leads to adding an important and effective element to society, otherwise, it may lead to deviation this general category of young people and then their society (Salman, 2006).

Many researchers have pointed out the importance of intellectual security for individuals and societies in educational institutions such as Noor (2007) and Fahjan (2012), this importance represented in the following:

- The educational institutions continue the process of socialization to shape the student's personality and to ensure his awareness of what is around him. It also teaches him his social duties.

- Expanding the scope of interaction, human relations, and interaction with different societal groups, through schools, institutes, students, teachers, and working staff.

- Linking students to the prevailing culture in society and introducing them to the heritage of their nation, spreading the spirit of innovation, creativity, and brilliance, in response to developments and changes in civilization in a way consistent with the foundations and principles of Islam.

- Integration of educational efforts between home, school, and society, to shape aware generation, who conscious of his rights and duties.

- Giving attention to studying social behavior and lifestyles and presenting them to young people in a simple way. Working in preparing the youth to be good members of their community.

- Training and accustoming young people to discipline, good behavior, the ability to understand the surrounding circumstances, and to deal with it in a balanced manner.

- Linking education and educational activities with societal efforts to create a balanced and proper education surrounded by religious and moral values, which achieve consistency with the environment in which an individual life. The role of the director in determining intellectual security in matters is determined by his cooperation with the student counselors, facilitating his capabilities to implement guidance and counseling programs, following up and observing general behavioral phenomena, and cooperating with the teaching staff and student counselors in evaluating wrong behaviors.

From the aforementioned, we conclude the importance of the role that the university administration plays through its profound impact on building students 'personality and providing guidance, and its endeavor to enrich his social interaction with his peers and teachers. In addition to monitoring their behaviors and adjust any unacceptable one.

The university administration also seeks to promote continuous communication between the school and the family to complement their roles in following up students, and in solving their economic, health and psychological problems, through establishing good relations between the administration of institutes and students and the faculty, so that an atmosphere of security and reassurance prevails in the university. Therefore, the university administration seeks to prepare and develop students with a healthy environment that aims to build a safe society that enjoys psychological and intellectual security, which it derives from an Islamic education that aims to achieve a balance between education and achieving intellectual security.

Many studies have addressed the subject of intellectual security such as the study of Hawari and Adon (2011), who conducted a study aimed at explaining the role of universities in promoting the principle of moderation and intellectual security for students. The researchers built a questionnaire. The random sample comprised of (400) deans, heads of departments, deputy heads of departments, and professors at the University of Laghouat in Algeria. The study concluded that the university administration plays a great role to promote the role of the professor in enhancing the principle of moderation and intellectual security.

Shaldan (2013) aimed to identify the role of colleges of education in Palestinian universities in enhancing intellectual security among their students. To achieve this goal, the descriptive and analytical approach was used, whereby a questionnaire was prepared and distributed to (395) students from the Faculties of Education at the Islamic University and Al-Aqsa University in Gaza. The study concluded the need to strengthen the role of colleges of education in Palestinian universities to enhance intellectual security, and to enable faculty members to play their role. In this area. The study found that there were statistically significant differences between the averages of the sample responses due to the gender variable and in favor of males, and there were no differences attributed to the effect of other variables.

Azzam (2017) conducted a study aimed at revealing the role of student clubs in enhancing intellectual security according to the perception of Islamic education from the viewpoint of students in the College of Education at Yarmouk University. The study sample consisted of (60) students. The questionnaire was used as a study tool, and the results of the study showed that clubs have a moderate effect on achieving intellectual security, and the study did not show differences attributed to variables (gender, specialization, and place of residence).

Abu Hamam (2017) investigated the degree of strengthening the role of the academic leaders in enhances intellectual 
security and its relationship to the degree of availability of job security in Jordanian universities in Amman. The descriptive survey method was used, the study sample consisted of (262) faculty members, the questionnaire was used as a tool for study. The results indicated that the degree of academic leaders' strengthening of intellectual security and the availability of job security in private universities in the capital Amman is high from the viewpoint of the faculty members. The results also showed that there were statistically significant differences in the degrees of academic leaders' strengthening of intellectual security and the availability of job security attributable to the gender and colleges, and in favor of females and human colleges, respectively, and they indicated no differences attributable to the impact of variables academic rank and years of experience.

Enzi (2018) conducted a study aimed to identify the role of the university activities in enhancing intellectual security, the descriptive approach was used. The study sample consisted of a group of books that dealt with intellectual security in the Arab Library and the management of student activities at King Saud University between Abdulaziz for Health Sciences, The content analysis, the morphological analysis method, and the scenario tool was used as a study tool. The study found that the weakness of psychological stability, the lack of electronic meetings regarding university activities, the speed and easy access to the electronic world with the difficulty of controlling it becomes a fertile ground for attracting and circulating destructive ideas that reinforce intellectual deviation. It also showed that the lack of understanding of the correct view of Islam, the weakness of dialogue, and the inadequacy of the role of universities to enhance intellectual security within the various university activities increases the manifestations of intellectual deviation, and that family disintegration, psychological problems and the lack of sports activities that help to invest the energies of youth, neglecting universities for their educational role increases the likelihood of intellectual deviation.

\section{Commenting on previous studies:}

The researcher has benefited from these studies in developing a tool for collecting information, identifying its results, and comparing them with the results of the current research. In addition to identifying the appropriate statistical treatments to be used, and in strengthening some opinions related to the theoretical framework. The current study is distinguished from previous studies attempting to identify the role of university administration in promoting intellectual security among Yarmouk University students from the students' point of view, for the academic year (2019/2020).

We conclude that the importance of this study is evident through the clarifying the university administration's role in enhancing the concept of intellectual security among students, and the extent to which its positive impact is reflected in the development of educational institutions and society, and the development of the educational process, to become a safe, professional and technical educational environment that achieves quality and meets the technical and professional needs of society.

\section{The study Problem}

Security is closely related to the educational process, as much as moral values are implanted in the souls of members of society, security and tranquility prevail in society. The multiplicity of reasons for deviation and dissolution has risen the attention to the responsibility of societies, universities, and the students towards making effort to preventing students from falling into the circle of deviation and in preserving the nation's intellectual security, especially in university. The weak role of the educational media in enhancing intellectual security, and addressing intellectual deviation, develops serious intellectual and security problems, hence the research idea that crystallized around the study problem started in answering the following main study question: What is the role of university administration in promoting intellectual security among Jordanian university students? And this question is divided into these sub-questions:

1 .What is the role of university administration in enhancing intellectual security among Yarmouk University students from their viewpoint?

2. Are there statistically significant differences at the level of significance $(\alpha=0.05)$ in the average responses of the participants due to variables: (gender, place of residence, and specialization)?

\section{The importance of the study:}

This study derives its importance from the importance of the topic it addresses and the goals it seeks to achieve, as the issue of intellectual security is considered one of the topics that opened new horizons for researchers to conduct other similar studies, by placing proposed perceptions before the university administration in Jordanian universities in revealing the reality of the role that the Jordanian university administrators play in enhancing intellectual security among students, through their interaction with faculty members, students and in participating in university events, developing slogans, and making plays and activities that contribute to activating their role in achieving students intellectual security.

It may benefit the students' category by showing the impact of intellectual security on students, the school, the family and society as a whole, and enriching the educational literature related to intellectual security, and this study may give a 
complete perception of the university administration about the current reality of their application of the concepts of intellectual security, its dimensions, and its functions.It can also derive its importance as it relates to a very important group in society, undergraduate students who have the oppressive ability to communicate with mixed groups in the university, which makes them more in need of fame and money from different sources without recognizing the actual source and how this act can reflect on their psychological, moral and social security.This study inspires researchers to conduct similar studies, according to other academic stages. It may provide a base about intellectual security that may assist in decision-making in providing specialized courses for faculty members on mechanisms that enhance students' intellectual security.

\section{Terms of the study:}

This study adopted the following terms:

The Role: A group of activities that achieve what is expected in certain situations. Roles can predict the behavior of the individual in different situations (Morsi, 2007: 109). The researcher defines it operationally as the expected function of the university administration in promoting the concept of intellectual security among students.

University Administration: These are the functions and tasks that classify administrative duties and tasks according to the laws and regulations of universities, which university administrators should perform, regardless of their administrative positions in the field of university education, to educate and enhance students' intellectual security, and to identify the negative effects of intellectual deviation and its consequences on students and his community. Which were measured by their responses to the study tool prepared for this purpose?

Intellectual Security: Hoshan (140: 2015) defines intellectual security as "an intellectual approach that adheres to moderation and aims to inculcate spiritual, moral, and educational values and purify it from extremist trends. "Operationally, it is defined as the undergraduate students' intellectually integrity and the free beliefs that are distant from deviations and wrong ideas that lead to the intellectual deviation, which is reflected in the security, reassurance, and stability of the individual and society. It is measured by the responses of the study sample members on the tool prepared for this purpose.

Jordanian universities: In this study, it means the bachelor's students in the Jordanian public and private universities affiliated to the universities of the Northern Jordan Region, which are: (Yarmouk University) in the academic year $(2019 / 2020)$.

\section{Study limits:}

The current study is limited to students of Jordanian public universities for the academic year (2019/2020). Its results are determined according to the study application procedures and the seriousness of the study sample in responding to the study tool, and psychometric properties related to validity and reliability.

\section{Method and procedures}

\section{Study approach:}

To achieve the goals of the study, the survey descriptive approach was applied.

\section{The study population and sample:}

The study population consisted of all the (74019) undergraduate male students at Yarmouk University according to the annual statistical report for the academic year 2019/2020. The Stratified random study sample consisted of (385) male and female students studying at Yarmouk University as shown in the following table

Table (1). Distribution of the study sample according to the independent variables

\begin{tabular}{|c|c|c|c|}
\hline \multirow{3}{*}{ Gender } & Category & NO. & Percentage \\
\hline & male & 195 & 50.6 \\
\hline & female & 190 & 49.4 \\
\hline \multirow[t]{3}{*}{$\begin{array}{l}\text { Place of } \\
\text { residence }\end{array}$} & city & 166 & 43.1 \\
\hline & countryside & 176 & 45.7 \\
\hline & Badia & 43 & 11.2 \\
\hline \multirow{3}{*}{$\begin{array}{l}\text { Specializa } \\
\text { tion }\end{array}$} & Humanitarian sciences & 193 & 50.1 \\
\hline & Natural sciences & 192 & 49.9 \\
\hline & Total & 385 & 100.0 \\
\hline
\end{tabular}




\section{Study Instrument:}

The questionnaire was built consisting of (30) items, distributed in three domains to measure the role of university administration in enhancing intellectual security among Yarmouk University students from the students' perspective, where a five-point scale was approved by giving each of the items one degree as the following: (Very high, high, moderate, low, and very low), and they are digitally represented $(5,4,3,2,1)$, respectively.

\section{Instrument correcting standard:}

The Likert 5-points scale was adopted to estimate the mean of the study instrument and its items. The statistical standard was adopted using the following equation:

\begin{tabular}{l|l|l|c|l}
\hline Very low & low & moderate & high & Very high \\
\hline $1.00-1.80$ & $1.81-2.60$ & $2.61-3.40$ & $3.41-4.20$ & $4.20-5.00$ \\
\hline
\end{tabular}

The scale was calculated using the following equation:

The highest grade (5) - the lowest grade (1) / the number of categories required (5)

$5-1 / 5=.80$

Then add (0.80) to each category.

\section{The validity and reliability of the study instrument}

Content validity was established by presenting it to (11) experienced arbitrators form the academic leaders and faculty members in the colleges of education in Jordanian universities to assess its relevance to what it measures and clarity. The final form of the questionnaire comprised of (21) items. The reliability of the instrument was verified by calculating the internal consistency coefficient through the Alpha Cronbach formula.

Table (2). The reliability of the study instrument for the domains in the Cronbach's' alpha method

\begin{tabular}{llll}
\hline Domains & & $\begin{array}{c}\text { Cronbach's } \\
\text { NO. } \\
\text { alpha value }\end{array}$ \\
\hline First domain & $\begin{array}{l}\text { revitalizing the role of students in enhancing their intellectual } \\
\text { security } \\
\text { promoting the role of activities in enhancing students' intellectual }\end{array}$ & 0.59 \\
Seconddomain & $\begin{array}{l}\text { security } \\
\text { Third domain }\end{array}$ & $\begin{array}{l}\text { Strengthening the community's role in enhancing } \\
\text { students 'intellectual security }\end{array}$ & 0.81 \\
Total & & 21 & 0.71 \\
\hline
\end{tabular}

The results in Table (6) indicate that the Cronbach's alpha consistency coefficients for the domains are high and range between $(0.59-0.81)$. Regarding the significance of validity and reliability, the researcher sees that the results of reliability are acceptable to achieve the goals of this study.

\section{Study variables}

Independent variables: gender, specialization, place of residence

Dependent Variables: The role of university administration in enhancing intellectual security among Yarmouk University students from their viewpoint.

Statistical treatments: The mean and standard deviations were used to answer the first and second question

\section{Discussion of results}

This section presents the statistical results that were reached after analyzing the data of the study instrument, indications of differences were revealed for the study variables by answering the study questions.

Results of the first question :What is the role of university administration in enhancing intellectual security among Yarmouk University students from their viewpoint?

To answer this question, mean and standard deviations for the role of university administration in enhancing intellectual security among Yarmouk University students were obtained as shown in Table (3): 
Table (3). Means and standard deviations for the role of university administration in enhancing intellectual security for Yarmouk University students from their point of view in descending order.

\begin{tabular}{lllll}
\hline Domain & Mean & SD & Rank & Degree \\
\hline $\mathbf{1} \quad \begin{array}{l}\text { The role of the university in revitalizing the role of students in } \\
\text { enhancing their intellectual security }\end{array}$ & 3.75 & 0.353 & 1 & high \\
$\mathbf{2} \quad \begin{array}{l}\text { The role of the university in promoting the role of activities in } \\
\text { enhancing students' intellectual security }\end{array}$ & 3.43 & 0.6 .6 & 2 & high \\
$\mathbf{3} \quad \begin{array}{l}\text { The role of the university in Strengthening the community's } \\
\text { role in enhancing students 'intellectual security }\end{array}$ & 3.42 & 0.552 & 3 & high \\
\multicolumn{2}{l}{ Total } & $\mathbf{3 . 5 3}$ & $\mathbf{0 . 4 3 1}$ & high
\end{tabular}

Table (3) indicates that the role of university administration in enhancing intellectual security among Yarmouk University students from their viewpoint is (high) with a mean of (3.53). As shown the mean of "the role of the university in revitalizing the role of students in enhancing their intellectual security" is (3.75) and with a high degree, followed by "The role of the university in promoting the role of activities in enhancing students' intellectual security" with a mean of (3.43), and also with a high degree. Where the last domain records a high degree and a mean of (4.2) which gauges the role of the university in Strengthening the community's role in enhancing students 'intellectual security. This result is consistent with the results of the Fehyan (2012) study, which indicates that administrators in university had a high impact on enhancing intellectual security among students. This result may be attributed to the keenness of the university administration to grant sufficient powers to its representative to exercise their roles in enhancing intellectual security among students and to face wrong and unacceptable behaviors. As they are entitled to hold training courses for members of the university administration to acquire the necessary skills to enhance the intellectual security of students and the skills of dialogue, persuasion, and dealing with deviant behavior.

The university administration always seeks to prepare and develop students within a healthy environment to build a safe society that enjoys psychological and intellectual security, which is derived from the Islamic education that aimed at achieving a balance between education and achieving intellectual security. The results may also be attributed to the fact that the administration enforces regulations and laws and hold accountable whoever violates it. This security system must be strong and honest to achieve its role properly. The Holy Qur'an urged the employee and worker to be characterized by strength and honesty. This result is consistent with what was reported on Al-Turki (2015), and Al-Shehri (2018) that the most important elements of intellectual security represented by implementing God's law among people because he is the only guarantor of justice and equality between people. In addition to having a strong security system that enforces laws among people equally. It also agrees with what Tomlinson (2006) pointed out in his study that university administrators and those working with it play a major role in enhancing intellectual security among students, through their efforts to spread concepts of values, ethics, and culture that are among the educational foundations that are built Undergraduate courses. This result differed with the result of Al-Anzi (2018), which showed weak psychological stability and the lack of electronic meetings in university activities and the speed and ease of access to the electronic world with the difficulty of monitoring it, which paves the ground for attracting and circulating destructive ideas that reinforce intellectual deviation, the lack of proper understanding of Islam and the weakness of dialogue and deficiencies in the role of universities in enhancing intellectual security within the different university activities increases the manifestations of intellectual deviation, and the family disintegration and psychological problems. The lack of sporting activities that invest the energies of youth in the absence of universities' educational role raises the risk of intellectual deviation.

The results of this study agreed with the results of Hawari and Adoun (2011), and Abu Hamam (2017), which concluded that the university administration plays a major role in strengthening the role of the faculty members in promoting the principle of moderation and intellectual security, while the result of the current study differed with the result of Azzam (2017), Enezi (2018), which revealed that the role of youth clubs in achieving intellectual security ranged between a moderate to low degree. The following is a detailed presentation to discuss each item in descending order according to the arithmetical mean in the results as follows:

The first domain: The role of the university in revitalizing the role of students in enhancing their intellectual security. 
Table (4). Means and standard deviations of the items of the first domain in descending order.

\begin{tabular}{llllll}
\hline Rank & NO. & Items & Mean & SD & Degree \\
\hline 1 & 3 & $\begin{array}{l}\text { The role of university administration in encouraging } \\
\text { students to make optima use of modern } \\
\text { technologies to identify community issues } \\
\text { (intellectual security) }\end{array}$ & 3.91 & 0.56 & high \\
$\begin{array}{l}\text { To encourage students to discuss issues posed in } \\
\text { society. }\end{array}$ & 13.81 & 0.58 & high \\
3 & 2 & $\begin{array}{l}\text { Ensure that the student is familiar with the concepts } \\
\text { and implications of intellectual security correctly }\end{array}$ & 3.81 & 0.57 & high \\
4 & $4 \quad \begin{array}{l}\text { Monitoring student behavior to identify any deviant } \\
\text { ideas }\end{array}$ & $\begin{array}{l}\text { Listening to students' problems and discussing them } \\
\text { including intellectual security issues }\end{array}$ & 3.72 & 0.72 & high \\
5 & 5 & 3.75 & $\mathbf{0 . 3 5}$ & high \\
\hline
\end{tabular}

The results indicated that the overall mean of the first domain (The role of the university in revitalizing the role of students in enhancing their intellectual security) is (3.75), standard deviation (0.35), and came at a (high) degree. This result may be attributed according to the participant's responses to the effective role that university administration exercises in educating students about the importance of intellectual security, and how to benefit from the various modern technologies, such as (the Internet, smartphones, Twitter, and Facebook) in developing their intellectual ability which is clearly indicated in item (3) that came in the first place and with a (high) degree. This high result, according to the respondents, is attributed to the fact that university administration provides a healthy environment for students to express their opinions about societal and intellectual issues, and it also promotes students' knowledge of various issues aiming to enlighten their ideas especially since undergraduate students are the youth of the future, the basis of the nation. This is indicated by item (2) which came at the second rank and with a (high) degree.

Promoting students in participating in dialogue about diverse topics including the society's issues and encouraging them to benefit from the available modern methods and techniques enable the student to be familiar with the correct concepts and contents of intellectual security. This is indicated by item (1) which came at the third rank and with a (high) degree . Besides the effective role the university administration plays in providing guidance, promoting dialogue and discussion, it also has a significant role in adjusting students' behavior and discarding negative behaviors that may lead to the loss of the student's academic, psychological, and societal future. This is indicated by paragraph (4) at the fourth rank and with a high degree. Although item (5) came in fifth place, it ranks high, which clearly affirms the university administration's keenness and awareness of the importance of listening to students' problems, discussing them, and getting to know their thoughts on the concept of intellectual security. And accordingly providing students with guidance when they misunderstood any ideas about this concept.

This result is consistent with the Qarni (2005) report that educational institutions take an active part in establishing security pillars at all levels of education by providing awareness and prevention, particularly at the university level and beyond, where students are active and vulnerable to a variety of positive or negative ideas. The high degree of this result is explained by what Faraj (2005) mentioned about the role of educational institutions in the process of socialization and formation of the student's personality, ensuring his familiarity with what is around him, and defining his social duties by linking the students with the prevailing culture in their society, and spreading the spirit of renewal Creativity and brilliance, in response to the developments and changes in civilization. The results of this study corresponded with the results of Hawari and Adoun (2011), and Abu Hamam (2017), which concluded that the university administration plays an influential role in strengthening the role of the faculty members in promoting the principle of moderation and intellectual security, while the result of the current study differed with the result of Azzam (2017) and Enezi (2018), which concluded that the role of clubs in achieving intellectual security ranged between moderate to a low degree.

The second domain: The role of the university in promoting the role of activities in enhancing students' intellectual security: 
Table (5). The mean and standard deviations for the second domain in descending order.

\begin{tabular}{|c|c|c|c|c|c|}
\hline Rank & NO. & Items & Mean & SD & Degree \\
\hline 1 & 8 & $\begin{array}{l}\text { Cooperate with the security services in the local community to } \\
\text { educate students about intellectual deviation }\end{array}$ & 3.73 & 0.62 & high \\
\hline 2 & 7 & $\begin{array}{l}\text { Publishing news about educational activities and programs on } \\
\text { intellectual security }\end{array}$ & 3.63 & 0.64 & high \\
\hline 3 & 4 & $\begin{array}{l}\text { Instruct students to participate in the memorization of the } \\
\text { Qur'an course held in university activities programs }\end{array}$ & 3.63 & 0.99 & high \\
\hline 4 & 6 & $\begin{array}{l}\text { Strengthening the relationship with media officials in } \\
\text { university administration to enhance students' intellectual } \\
\text { security }\end{array}$ & 3.46 & 0.99 & high \\
\hline 5 & 3 & $\begin{array}{l}\text { Benefiting from the experiences of the Imam of the } \\
\text { neighborhood Mosque in the direct personal orientation of } \\
\text { some students }\end{array}$ & 3.45 & 1.00 & high \\
\hline 6 & 2 & $\begin{array}{l}\text { Calling imams of mosques to advise students on religion and } \\
\text { intellectual security. }\end{array}$ & 3.43 & & high \\
\hline 7 & 1 & $\begin{array}{l}\text { Contact the imams of the mosques and inform them about the } \\
\text { security problems of students }\end{array}$ & 4.46 & .75 & high \\
\hline \multirow[t]{2}{*}{8} & 5 & $\begin{array}{l}\text { Directing students to participate and benefit from the religious } \\
\text { guiding programs and activities offered by the university } \\
\text { administration }\end{array}$ & 4.41 & .85 & high \\
\hline & & The overall mean & 3.43 & 0.61 & high \\
\hline
\end{tabular}

The results of the second domain (The role of the university in promoting the role of activities in enhancing students' intellectual security) records a mean of (3.43), standard deviation (0.61), and a (high) degree. Which may be attributed according to participants to the importance of the university cooperation and coordination with the security services in the local community that seeks to educate students at the university stage about the importance of security and safety, especially the students' intellectual security in light of the vast amount of knowledge they can access via social media and technical means. Therefore, students must be aware of the importance of the knowledge that enhances their thought and learning, and to distance themselves from ideas that contribute to their intellectual deviation. The result may also be due to the university administration's awareness of the importance of educating students about the wrong and deviant ideas and this is what indicate in item (8) which came in the first place and with a high degree.This high result may be attributed to the university administration's awareness of the importance of the university activities, programs, and extracurricular activities in publishing targeted topics related to intellectual security and linking them to education and educational activities. In addition to the importance of cooperating with the community to shape a balanced generation who is committed to his religious values and ethics. The university administration can achieve intellectual security through its cooperation with the student counselor and facilitating the implementation of guidance and counseling programs, following up, and observing general behavioral phenomena. It also can cooperate with the teaching staff and the student counselor in evaluating students' wrong behaviors. This is what indicated by item (7), which ranked second and with a high degree.

This high result may be attributed to the importance of the Islamic religion in implanting the values of security and safety, and educating students to differentiate between the lawful and the unlawful acts, and enlightening them to distinguish between the right and wrong things, and since we are an Islamic society, it is our priority to implant the values and principles of our true religion, which rejects the party and deviation, so the student who memorizes the Qur'an surely applies what he memorized and it is not easy to change his ideas negatively. This is indicated by item (4), which ranked third and with a high degree. Item (6) which states that "Strengthening the relationship with media officials in university administration to enhance students' intellectual security" ranked fourth and with a high degree, which may be attributed to the role played by those responsible for managing the media from assisting students in any situation that they may be exposed to by any other non-security authority aimed at harming the youth category, in addition to the role of officials in enhancing students 'intellectual awareness, whether through the fostering educational and counseling programs by informing students of stories and facts about extremism and delinquency, so that students can learn from them. 
Item (3) also came to a high degree, this may be attributed to encouraging and instructing students to benefit from the experiences of those with expertise and specialization close to their place of residence they can guide them to acquire the good morals and rejecting extremism and terrorism, which is recommended by our true religion. Item (2) specified that "Calling imams of mosques to advise students on religion and intellectual security". obtained a high degree, this result may be attributed to the awareness of university administration of the importance of the influence of specialists such as imams of mosques on the student behavior and thoughts through their style and tone of voice and their way of communicating the idea to students about the impact of intellectual deviation, and the importance of intellectual security. Preachers and imams are the parties that influence the youth category because they can attract young ideas.

"Contact the imams of the mosques and inform them about the security problems of students" this item came at the seventh rank according to the participants' responses which may be attributed to the fact that the majority of students are afraid that someone will know about their behavioral problems. Informing the university administration about their behavior means that their acts will be reported to everyone through a speech That may be spoken by the imam regarding a particular issue or act related to student conduct that embarrasses a student who may believe it is meant for him, so students are keen not to tell the Imams, especially on issues of security and extremism. This is indicated by item (1) and with a high degree.

Item (5) came in a high degree at the end of the field, and the reason for this last result, which came in a moderate degree, is because most of those who participate in activities and programs in light of the widespread terrorism in our societies, which entered our fields quickly, are aware of the abuse from others who considered doing religious activities of Islam as the conduct of extremist or terrorist ideology. This result was in agreement with the findings of the Nakpodia (2010), which concluded that the importance of strengthening the educational foundations related to culture is the best way to familiarize students with the rules of Nigerian culture, its types, advantages, and changing factors and that the faculty member implementation of the cultural issues in the university curriculum make students feel satisfied with the components of the curriculum and its basics. The results of this study were in agreement with the result of the Tomlinson (2006), which revealed a high degree of the role that each administration plays in enhancing intellectual security among students, through their efforts to spread concepts of values, ethics, and culture.

The results of this study are consistent with the results of Hawari and Adoun (2011), and Abu Hamam (2017), which concluded that the university administration plays a major role in motivating the role of the professor in promoting the principle of moderation and intellectual security, while the result of the current study differed with the result of Azzam (2017) and Enezi (2018), which concluded that the role of clubs in achieving intellectual security ranger from moderate to a low degree.

Third domain: The role of the university in strengthening the community's role in enhancing students 'intellectual security

Table (6). Mean and standard deviations for the third domain in descending order.

\begin{tabular}{|c|c|c|c|c|c|}
\hline Rank & NO. & Items & Mean & SD & Degree \\
\hline 1 & 5 & $\begin{array}{l}\text { Preparing a plan and schedule for developing the relationship } \\
\text { with the local community institutions to provide awareness } \\
\text { programs for students to enhance their intellectual security }\end{array}$ & 3.70 & 0.96 & high \\
\hline 2 & 4 & $\begin{array}{l}\text { Inviting security officials to provide advice and direct } \\
\text { awareness to enhance their intellectual security }\end{array}$ & 3.62 & 0.89 & high \\
\hline 3 & 1 & $\begin{array}{l}\text { Inviting experts to provide advice and guidance to students } \\
\text { through preaching and counseling lessons to enhance their } \\
\text { intellectual security. }\end{array}$ & 3.45 & 0.79 & high \\
\hline 4 & 2 & $\begin{array}{l}\text { Directing students to participate in the memorization of the } \\
\text { Qur'an courses held in university activities programs }\end{array}$ & 3.26 & 0.87 & $\begin{array}{l}\text { modera } \\
\text { te }\end{array}$ \\
\hline 5 & 3 & $\begin{array}{l}\text { Providing educational guidance activities and disseminating } \\
\text { them through the available media to enhance their intellectual } \\
\text { security. }\end{array}$ & 3.26 & 0.87 & $\begin{array}{l}\text { modera } \\
\text { te }\end{array}$ \\
\hline \multirow[t]{2}{*}{6} & 6 & $\begin{array}{l}\text { Employing University programs and activities to enhance } \\
\text { students' intellectual security }\end{array}$ & 3.19 & 1.02 & $\begin{array}{l}\text { modera } \\
\text { te }\end{array}$ \\
\hline & & The overall mean & 3.42 & 0.55 & high \\
\hline
\end{tabular}

The results indicate that the third field (The university role in strengthening the community's role in enhancing students' intellectual security) came at the third level, with an average score of (3.42), and a standard deviation of (0.55), and with a grade of (high). This high result is attributed to the importance of the role played by the university administration in preparing a schedule and plan (i.e. organizing meetings with important experienced persons from the local 
community) within specific and clear periods that take into account their readiness to provide the experiences and knowledge to educate students about the issues related to intellectual security. Given the specificity and sensitivity of the undergraduate stage, which is accompanied by many tensions and changes that make the youth vulnerable to any party intended to corrupt their ideas and beliefs. This is shown by item (5) which came first with a (high)degree.

Item (4) ranked second with a high degree. The researcher sees that inviting people in charge to provide direct advice and awareness to enhance students intellectual security is of importance, and they can refer to actual examples from the stories and experiences of other people so that students can learn from their experiences in combating any negative efforts tend to poison their thoughts. While item (1) ranked third, and this result may be attributed to the importance of the community's participation in educating students especially through benefitting from the religious aspects that can play a significant role in inculcating the principles of Islamic awareness in the hearts of students through ways and methods of preaching and guidance.

Item (5) states that "Providing educational guidance activities and disseminating them through the available media to enhance their intellectual security." came in fifth place with a mean of (3.26) and a (moderate) degree. Actually, the university administration has no authority except within its institution, they can only guide within their powers, while the media can exceed the boarder and raises the awareness of all members of the local community, including the students.

Item (2), which is "directing students to participate in the memorization of the Qur'an courses held in university activities programs," ranked fourth among the items related to the field of strengthening the role of society in enhancing intellectual security among students with a mean (3.26) and a moderate degree. This moderate result may be attributed to the fact that, the principal does not have absolute authority over the student outside the walls of the university, and that the participation of students in memorizing the Qur'an is unsystematic participation stemming from the desire of the student himself.

Item (6), which is "Employing University programs and activities to enhance students' intellectual security," ranked sixth among the items related to the field of strengthening the role of society in enhancing intellectual security among students with a mean (3.19), and a standard deviation (1.023). The reason for this moderate degree is due to the large burdens entrusted to the university administration, and the faculty member and students who spend most of his studying to move to a new educational stage. These burdens limited the limited students' participation in any activity. The results of this study are consistent with the results Hawari and Adoun (2011), and Abu Hamam (2017), which concluded that the university administration plays a major role to activate the role of the faculty members in promoting the principle of moderation and intellectual security, while the result of the current study differed with the result of Azzam (2017), Enezi (2018), which concluded that the role of clubs in achieving intellectual security ranged between a moderate to low degree.

The answer to the second question: Is there statistically significant differences at the level of significance $(\alpha=0.05)$ in enhancing intellectual security for Yarmouk University students due to variables (gender, specialization, and place of residence)?

To answer this question, mean and standard deviations for enhancing intellectual security among Yarmouk University students were extracted by gender, specialization, and location of residence. The table below shows that. 
Table (7). Mean and standard deviations for the role of university administration in enhancing intellectual security among Yarmouk University students from their viewpoint, according to gender, place of residence, and specialization

\begin{tabular}{|c|c|c|c|c|c|}
\hline \multirow{4}{*}{ Gender } & \multirow{3}{*}{ male } & \multirow[b]{2}{*}{ mean } & \multirow{2}{*}{$\begin{array}{l}\text { Student's role } \\
3.87\end{array}$} & \multirow{2}{*}{$\begin{array}{l}\text { Activity role } \\
4.21\end{array}$} & \multirow{2}{*}{$\begin{array}{l}\text { Community role } \\
4.23\end{array}$} \\
\hline & & & & & \\
\hline & & SD & .472 & .600 & .500 \\
\hline & female & mean & 3.94 & 4.36 & 4.38 \\
\hline \multirow{4}{*}{$\begin{array}{l}\text { place of } \\
\text { residence }\end{array}$} & \multirow{3}{*}{ city } & $\mathrm{SD}$ & .396 & .394 & .414 \\
\hline & & mean & 3.95 & 4.34 & 4.33 \\
\hline & & $\mathrm{SD}$ & .426 & .443 & .458 \\
\hline & \multirow[t]{2}{*}{ countryside } & mean & 3.85 & 4.16 & 4.27 \\
\hline \multirow{7}{*}{$\begin{array}{l}\text { Specializa } \\
\text { tion }\end{array}$} & & $\mathrm{SD}$ & .453 & .581 & .480 \\
\hline & \multirow[t]{2}{*}{ Badia } & mean & 3.97 & 4.54 & 4.41 \\
\hline & & $\mathrm{SD}$ & .394 & .301 & .419 \\
\hline & \multirow[t]{2}{*}{$\begin{array}{l}\text { Humanitari } \\
\text { an sciences }\end{array}$} & mean & 3.91 & 4.24 & 4.28 \\
\hline & & $\mathrm{SD}$ & .475 & .572 & .518 \\
\hline & \multirow{2}{*}{$\begin{array}{l}\text { Natural } \\
\text { sciences }\end{array}$} & mean & 3.90 & 4.32 & 4.34 \\
\hline & & $\mathrm{SD}$ & .396 & .446 & .406 \\
\hline
\end{tabular}

Table (7) shows an apparent variation in the means and standard deviations of the role of university administration in enhancing intellectual security among Yarmouk University students due to the variables gender, place of residence, and specialization.

Regarding the gender variable, the results indicate that: There are statistically significant differences $(\alpha=0.05)$ attributable to the effect of gender in all domains except for the students' role, and the differences came in favor of females. The researcher believes that females have more interest than males in preserving the security identity and the integrity of thought from extremism since the female is considered the basis of the family and raises her children to love the homeland, love of society, and respect for others. While males, their greatest interest is to gain money from different resources, so they are more vulnerable to exposure to intellectual deviations, and therefore here the role of university administration in strengthening the awareness of youth about the importance of intellectual security. This finding is consistent with the result of the Shaldan (2013), which pointed out that the differences were due to the effect of the gender variable. This result is inconsistent with the Olayan (2014), where its results showed that there were no statistically significant differences at the level of significance $(\alpha=0.05)$ in a degree of students' commitment to the citizenship values attributed to the gender variable.

The variable of specialization, it is found that there are no statistically significant differences $(\alpha=0.05)$ due to the effect of specialization on all domains. This means that Yarmouk University students do not have a difference in their views on the domains of intellectual security, according to their different specializations, whether humanity or natural sciences. This indicates that the type of specialization has no relationship in determining the nature of students' thoughts, as students may be exposed to some stimuli that develop their negative intellectual attitudes, which may his future negatively. Hence, here the role of university administration in providing awareness, advice, and guidance to all students at Yarmouk University at different specializations is manifested. This result is inconsistent with the study of the Shaldan (2013) and Azzam (2017), where its results showed that there were no differences.

The place of residence variable, the results reveals that: There are no statistically significant differences $(\alpha=0.05)$ due to the effect of the place of residence. This means that Yarmouk University students do not have a difference in their views on the domains of intellectual security, according to the different place of residence, whether they are from the countryside, Badia, or the city, because the university administration seeks to enhance the intellectual security of all students. This result agrees with the results of Abu Al-Hamam (2017) and Azzam (2017), which states that there were no differences attributable to the variable of the place of residence. 


\section{Conclusion}

Through the presentation of the results, we can conclude that the role of university administration in enhancing intellectual security among Yarmouk University students, from their viewpoint, which came to a high degree, indicates the awareness of the university administration at Yarmouk University in educating students and strengthening their intellectual side, and its keenness to enhance intellectual security as represented by the following:

- The first domain: The role of university administration in enhancing intellectual security among students: which obtained a high degree, and this shows the extent of the university care to enhance its student awareness towards intellectual issues. This domain has ranked first according to the students' responses as the university urge its students to make the best use of modern technologies to identify the important issues facing their community ( Intellectual Security), providing students with an opportunity to discuss issues raised in society, ensuring that the students are familiar with concepts and implications of intellectual security correctly, and monitoring students' behavior to identify and monitor deviant ideas.

- The second domain: The role of university administration in promoting university activities to enhance intellectual security among students, where it obtained the second rank and with a high degree, and this indicates the university administration's keenness to engage students in programs and activities that enhance their intellectual security. It also seeks to cooperate with community security services to educate students about intellectual deviation, publishing information about intellectual security, directing students to participate in the Quran memorization courses, and strengthening the relationship with media officials in the neighborhood to enhance students' intellectual security.

- The third domain: The role of the university in Strengthening the community's role in enhancing students 'intellectual security: Its came in the third and last rank, and with a high degree, and this indicates the keenness of the university administration in preparing a plan and schedules for developing the relationship with local community institutions to urge them to provide responsiveness programs for students to enhance their intellectual security, invite security officials to advise and direct students to participate and benefit from programs and activities that enhance their intellectual security.

\section{Recommendations:}

By analyzing the results of the study, the researcher recommends the following:

- Enhancing communication with the university administration and informing them about students' security problems.

- Providing educational activities and disseminating them through the available media to enhance their intellectual security.

- Employing the university programs and activities to enhance students' intellectual security.

- Providing a full opportunity for free and rational dialogue within a single society: and correcting the intellectual distortion by argument and persuasion.

- Promote interest in education in schools, mosques, homes, and other community institutions.

- Instilling the values of loyalty and belonging to the homeland is one of the strongest pillars that must be taken care of in order for students to keep away from everything that harms the nation.

- Familiarizing the student with his social functions and ensuring his familiarity with them, University education is a human and social function before it is informational.

- Connecting students to the prevailing culture in society and introducing them to the heritage of their nation, while spreading the spirit of innovation, creativity and brilliance, in response to developments and changes in civilization while not contradicting the foundations and constants of religious beliefs.

- Training and accustoming students to discipline, good behavior, and the ability to understand the surrounding circumstances and deal with balance within its framework, wisely away from extremism and negative ideas

\section{References}

Abu Hamam, F. (2017). The degree to which academic leaders enhance intellectual security and its relationship to the degree of availability of job security in Jordanian universities in the capital, Amman (unpublished Master Thesis), Middle East University, Jordan.

Ajez, P., \& Nshwan, J. (2005). Problems facing students of studies in Palestinian universities," Islamic University, Gaza

Azzam, M. (2017). The role of student clubs in enhancing intellectual security according to the perception of Islamic education from the viewpoint of students of the Faculty of Education at Yarmouk University, "The Conference of 
Education Challenges and Future Prospects, for the period from 27-25 April, Yarmouk University - College of Education, Jordan.

Barashi, B. (2011). The role of intellectual security in preventing terrorism: an applied study in the Yemeni Republic. (Unpublished Master Thesis), Naif Arab University for Security Sciences, Saudi Arabia.

Barro, R., \& Lee, W. (2013). A New Data Set of Educational Attainment in the World, 1950-2010. Journal of Development Economics, 104, 184-198. https://doi.org/10.1016/j.jdeveco.2012.10.001

Buqami, N. (2009). The impact of transformation into an information society on intellectual security. The First National Conference on Intellectual Security, Concepts, and Challenges. From 18-15 / 5. Prince Nayef bin Abdulaziz Chair for Intellectual Security Studies at King Saud University / Saudi Arabia

Dhafiri, L. (2017). The role of school administration in enhancing intellectual security for secondary school students in Afif Governorate. (Unpublished Master Thesis), King Abdulaziz University, Saudi Arabia. https://platform.almanhal.com

Ekpenyong, E. (2011). Foundation of Technical Education: Evolution and Practice for Nigerian Students in Technical and Vocational Education and Adult Education, Policy Makers, and Practitioners. Benin City: Ambix Press Ltd.

Enezi, A., \& Al-Zouboun, S. (2017). Suggested educational foundations to develop the concept of intellectual security among secondary school students in the Kingdom of Saudi Arabia. Studies Journal of Educational Sciences, 42(2), 641-659.

Enezi, N. (2018). The role of the University Activities Department in enhancing intellectual security. (Unpublished Master Thesis), Naif Arab University for Security Sciences

Fahjan, N. (2012). The role of the school administration in enhancing the intellectual security of secondary school students in the governorates of Gaza and ways to activate it. (A magister message that is not published). The Islamic University of Gaza.

Hakim, N. (2009). Towards a national strategy to consolidate the concept of intellectual security in society. The first national conference on intellectual security, concepts, and challenges. For the period from 18-15 / 5. Prince Nayef bin Abdulaziz Chair for Studies on Intellectual Security at King Saud University / Saudi Arabia

Hatamleh, H., \& AL Darawsha, N. (2019). The Challenges of the Application of the Productive University's Philosophy in Jordanian Universities and Ways of Developing Them from The Perspective of Academic Leaders. Journal of Institutional Research South East Asia, 17(1), Acceptable for publication. 4/5/2019

Hawari, M., \& Adon, N. (2011). The role of universities in promoting the principle of moderation and intellectual security for students (field study on the University of Laghouat in Algeria). Conference on the Role of Arab Universities in Promoting the Principle of Moderation among Arab Youth, for the period from 6/9/2011 2/9, Taibah University, Medina

Hoshan, B. (2015). The importance of the school in enhancing intellectual security. The Journal of Police Thought, 94(24), 231-258.

Hudlaa, M. (2012). Intellectual security concept, challenges, and means of protection from intrusion. Al-Jazirah Newspaper, No. (14374), retrieved from the source on http://www.al-jazirah.com/

Khamisi, S. (2002). Studies in Arab education in Arab society issues. Alexandria, Abo Al Wafa House for Publishing and Distribution.

Morsi, M. (2007). Educational reform and renewal in the modern era. Cairo: Book World House for Publishing and Distribution.

Nakpodia, D. (2010). Culture and curriculum development in Nigerian Schools, African Journal of History and Culture (AJHC), 2(1), 1-9.

Nasser, M. (2016). The role of the school administration in enhancing the intellectual security of Al-Azhar high school students in Al-Gharbia Governorate Journal of Arab Studies in Education and Psychology (ASAP), 72, 379- 416.

Nour, A. (2007). The concept of intellectual security in Islam and its educational applications (unpublished master's thesis), Umm Al-Qura University, Makkah Al-Mukarramah, Saudi Arabia.

Omari, B. (2005). Motives for enrollment in postgraduate studies among Jordanian public university students as seen by postgraduate students for the academic year 2003/2002. Journal of Studies, Educational Sciences, 1(32), 155-140.

Qarni, M. (2005). Security responsibility for educational institutions. A working paper presented to the Society and Security Symposium, King Fahd Security College in Riyadh from 2/21 - 2/24 in 2005 
Salman, I. (2006). The role of school administrations in enhancing students' intellectual security, (unpublished master's thesis), Naif Arab University for Security Sciences, Saudi Arabia.

Shahri, N. (2018). Elements of intellectual security. Retrieved from https://shms.sa

Shaldan, F. (2013). The role of educational colleges in Palestinian universities in enhancing intellectual security for their students and ways to activate it, Journal of the Islamic University for Educational and Psychological Studies, 21(1).

Tayyar, M. (2011). The role of school administration in activating security education from the viewpoint of educational supervisors in the General Administration of Education in Riyadh. (Unpublished Master Thesis), Imam Muhammad Bin Masoud Islamic University, Medina, Saudi Arabia.

Tomlinson, J. (2006). Values: the curriculum of moral education, Online Article, Children and Society Journal, 11(4), 242-251. https://doi.org/10.1111/j.1099-0860.1997.tb00033.x

Turki, P. (2015). The most prominent elements of intellectual security. Retrieved from https://www.assakina.com

Young, S (2014). Does a master's degree make you any more employable? Retrieved from https://www.independent.co.uk

\section{Copyrights}

Copyright for this article is retained by the author(s), with first publication rights granted to the journal.

This is an open-access article distributed under the terms and conditions of the Creative Commons Attribution license which permits unrestricted use, distribution, and reproduction in any medium, provided the original work is properly cited. 